\title{
EXPOLRING RATOON PROSPECTIVE OF SUGARCANE VARIEITES / CLONES AT TOBA TEK SINGH
}

\author{
Waqas Raza Arshad*, Muhammad Ehsan* and Zaheer Aslam** \\ * Research Officer, Sugarcane Research \& Development Board, Faisalabad. \\ ** M. Sc (hons). Student, University of Agriculture Faisalabad.
}

\begin{abstract}
Sugarcane is the crop that have the quality to sprout after its first harvesting, phenomenon known as ratooning. Among all other major crops, sugarcane ratooning is widely acceptable to farmers of the Punjab. The more the tillers grew, the higher are the chances of a greater number of stalks to be harvested. It is proven that more the number of stalks, the thinner is the diameter, finally results in more stalks and high production. Similarly, higher number of canes produce favorable ratoon. In this experiment, performance of Seven promising sugarcane varieties/clones along with the check variety CPF-246, were tested for their ratoon ability capacity at farmer's field at Toba Tek Singh during the year 2017-18. It has been found that one of the varieties S2008-FD-19 produced that maximum ratoon yield, U2003-US-633 produced the maximum sugar recovery and S2003-US-133 produced maximum number of mill able canes. The observing of the current analysis also revealed that S2003-US-633 and S2003-US-133 have significant potential for boom sugar recovery through breeding programs and by improving the production techniques.
\end{abstract}

Key words: Sugarcane, Yield, Ratoon ability, Punjab

\section{INTRODUCTION}

The solution of problems with low sugar yields and sugar recovery can be solved with the help of improved sugar cane varieties (3). Significant work is being done to increase the production of sugarcane using high-yielding varieties and the use of advanced production technologies (5). Ratoon crops are economical for Pakistani agricultural communities because production costs are $30 \%$ lower than crop plants, saving seed material provides additional benefits. However, for renewable plants, more than $25 \%$ of $\mathrm{N}$ fertilizer (8) should be used over an approved $\mathrm{N}$ dose.

The unique productivity potential of different varieties with renewable products is important for maintaining high productivity. Now the wide range of different varieties depends to a great extent on their reproductive potential. Therefore, sugarcane varieties that perform well in plants and renewable products should be promoted for commercial cultivation.

The purpose of this study was to assess the productivity and quality of the sugar cane regeneration of some of the promising varieties/clones at the Usman farms, Chak No. 286 J.B. Toba Tek Singh. 


\section{MATERIALS AND METHODS}

\section{Study Area:}

The study was conducted at the Farm area of Chak No. 286 J.B. Toba Tek Singh during crop season 2017-18. The soil is loamy with $\mathrm{pH}$ of 7.8, EC $\left(0.87 \mathrm{dsm}^{-1}\right)$ and organic matter (OM) of 0.73 (\%).

\section{Establishment of Experiment:}

The experiment was arranged in randomized complete block design(RCDB) with three replications and plot size of 6 $x \quad 8 \mathrm{~m}$. Seven sugarcane varieties/clones, viz; S2003US-633, S2008-FD-19, S2003-US-133, CPF-246, CPF-247, CPF-249 and CPF246 were obtained from Shakarganj Sugar Research Institute, Jhang and sown at farm area of Chak No. 286 J.B. on February 20, 2016. All the standard agronomic practices and other farm operations were carried out as and when required.

Crop was sown in $120 \mathrm{~cm}$ apart trenches at a seed rate of 75000 double budded setts per hectare. The fertilizer was applied @ 168-112-112 kg NPK per hectare to fresh crop and $30 \%$ more NPK was given to ratoon crop.

\section{Data Recording and Statistical Analysis}

Harvesting was completed on 10 December, 2017 and data of $1^{\text {st }}$ ratoon crop was recorded for different parameters which include number of sprouts and cane count. Obtained data was statistically analyzed and Least Significant Difference (LSD) was performed. Final harvesting was completed in January, 20, 2018 and data regarding cane yield and sugar recovery was recorded.

Ten random selected canes of each variety were taken and sent to the laboratory for qualitative analysis and were crushed in a power cane crusher for juice extraction. Brix readings were documented by brix hydrometer standardized at $20^{\circ} \mathrm{C}$. Sucrose percentage was determined by Horn's dry lead sub-acetate method of sucrose analysis (13). The commercial cane sugar (CCS $\%$ was recorded in the laboratory using the below formula:

$\mathrm{CCS} \%=3 \mathrm{P} / 2\{1-(\mathrm{F}+5) / 100\}-$ $\mathrm{B} / 2\{1-(\mathrm{F}+3) / 100\}$

Where
P stands for pol percentage (sucrose percentage), $\mathrm{F}$ for fiber percentage and $B$ for Brix percentage (13). The data was analyzed statistically. The treatment means was compared by Fisher's analysis of variance techniques and least significant difference test (12).

\section{RESULTS AND DISCUSSION}

\section{Tiller/Sprouts Population}

From the farmer's perspective, farming is the most desirable feature. Good planting provides good planting position and end productiveness and better restorative ability of sugarcane plants (6). The extent and nature of tillering till maturity is largely a varietal character. It is also influenced by the light and temperature available in the field. The data in Table 1 show that there is no significant difference between the rods. The maximum number of sprouts (101.13) was observed in the S2008-FD-19. However, this difference did not differ significantly from the CPF$246 \quad$ (100.13). CPF-249 showed the least number of buds (82.27). 
Table-1 Mean values of Parameters representing ratooning ability of different varieties

\begin{tabular}{|c|l|c|c|c|c|}
\hline $\begin{array}{c}\text { Sr. } \\
\text { No. }\end{array}$ & Variety & $\begin{array}{c}\text { Sprouts } \\
\left(\mathbf{0 0 0} \mathbf{~ h a}^{-1} \mathbf{)}\right.\end{array}$ & $\begin{array}{c}\text { Cane count/ } \\
\text { Mill able canes } \\
\left(\mathbf{0 0 0} \mathbf{~ h a}^{-1} \mathbf{)}\right.\end{array}$ & $\begin{array}{c}\text { Cane Yield } \\
\left.\mathbf{( t ~ h a - 1}^{-1}\right)\end{array}$ & $\begin{array}{c}\text { Sugar recovery } \\
\mathbf{( \% )}\end{array}$ \\
\hline 2 & S2008-FD-19 & $101.13 \mathrm{a}$ & $92.17 \mathrm{~b}$ & $78.87 \mathrm{~b}$ & $10.48 \mathrm{bc}$ \\
\hline 3 & S2003-US-633 & $89.32 \mathrm{~cd}$ & $83.57 \mathrm{c}$ & $73.77 \mathrm{c}$ & $11.29 \mathrm{a}$ \\
\hline 4 & S2003-US-133 & $92.33 \mathrm{c}$ & $97.13 \mathrm{a}$ & $85.10 \mathrm{a}$ & $10.81 \mathrm{~b}$ \\
\hline 5 & CPF-246 & $100.13 \mathrm{ab}$ & $95.60 \mathrm{ab}$ & $74.60 \mathrm{c}$ & $10.04 \mathrm{c}$ \\
\hline 6 & CPF-247 & $98.43 \mathrm{~b}$ & $85.40 \mathrm{c}$ & $70.37 \mathrm{~d}$ & $10.02 \mathrm{c}$ \\
\hline 7 & CPF-249 & $82.27 \mathrm{~d}$ & $84.13 \mathrm{c}$ & $72.03 \mathrm{~d}$ & $10.15 \mathrm{c}$ \\
\hline
\end{tabular}

\section{Cane Count/ Mill able Canes}

Junejo et al. (7) claimed that mill able canes is an important sugar yield contributing factor Observations recorded in this study reveal (Table 1) that maximum number of cane count (97.13) were observed in S2003US-133. This variety showed significant difference from all the other varieties and no variety represented number of mill able canes up to the number represented by S2003-US-133. Minimum number of mill able canes (83.57) were observed in
S2003-US-633. Maximum number of mill able canes in case of S2003-US-133 might be due to the higher number of sprout presence as compared to other varieties. This has also been claimed by Matin et al. (9) and Alam et al. (1).

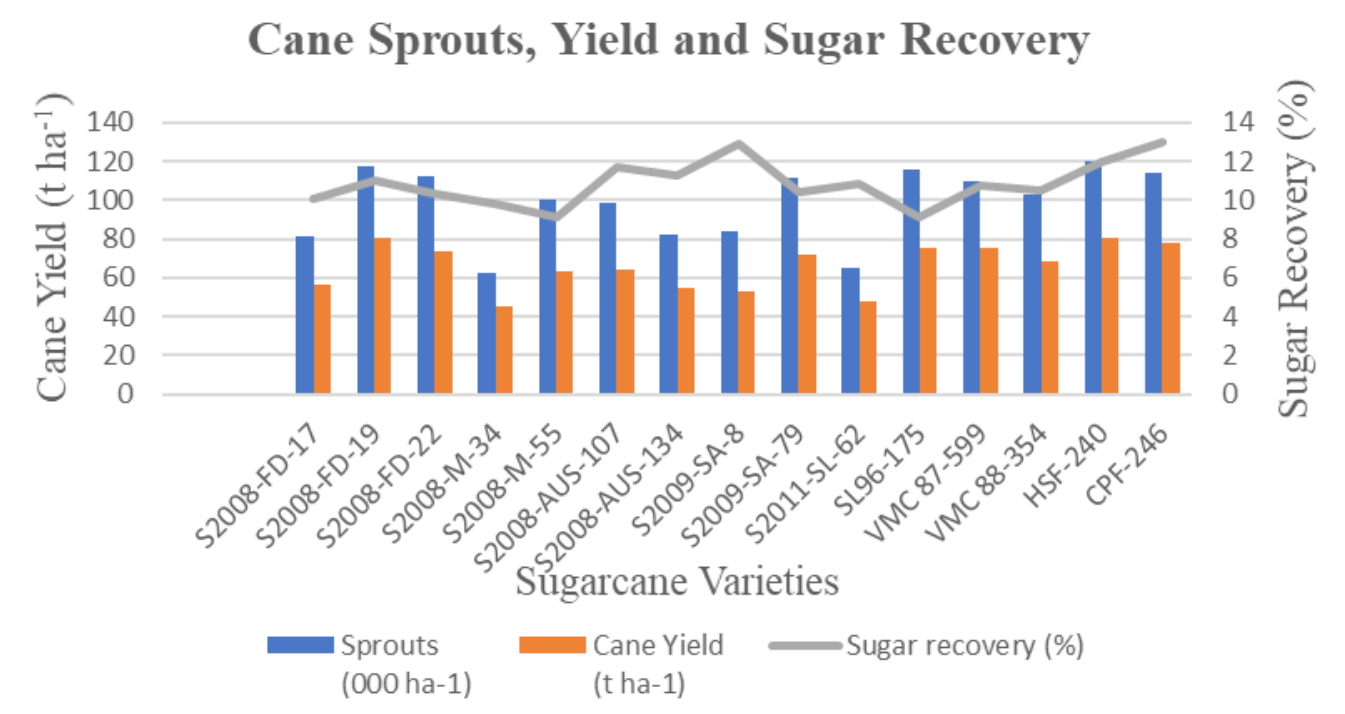

Fig1. Comparison between cane sprouts, yield and sugar recovery

\section{Cane Yield}

Cane yield is a polygenic character; multiple genes are involved controlling cane height, thickness, tillering, germination and internodes pattern. By and large plant characters like root system, leaf growth, vigor, lodging etc all in one form or the other affect yield. All the breeding programs, production ever-evolving development of newer technologies are aimed at enhancing the crop yield. This prime focus has enabled human being to pave the way for food security. From the observed data (Table 1), it is evident that maximum cane yield was observed in S2003US-133 (85.10 t ha-1) and showed significant difference with S2008-FD-19 which represented $78.87 \mathrm{t} \mathrm{ha}^{-1}$ yield. It is noteworthy to mention 
that there was no significant difference in the number of sprouts among both varieties but there was significant difference in terms of cane count/ number of millable canes. Minimum cane yield was obtained in case of CPF$247\left(70.37 \mathrm{t} \mathrm{ha}^{-1}\right)$.

\section{Sugar Recovery (\%)}

Total soluble solid or brix (\%) is the percent amount of sugars and minerals dissolved in water. Different chemicals can be considered as responsible factors for the fluctuation in the brix reading (MO et al., 2018). Maximum sugar recovery (11.29\%) was observed in S2003-US-633 while minimum (10.02 \%) was found in CPF-247. It can be admitted that all the three evaluated parameters contributed to different levels for having significantly different Sugar recovery percentage

\section{CONCLUSION}

From above discussion, it is evident that number of sprouts are an important considerable factor for the sugar yield and sugar recovery. But it can also be admitted that in some situations, this trend is was not found in case of S2003US-633 which stood at fourth number in case of number of sprouts, third in case of yield of sugarcane but it gave maximum sugar recovery (11.29\%) as compared to other 6 tested sugarcane varieties. It can be inferred that all the factors are important and good agronomic practices also contribute in enhancement of yield and sugar recovery.

\section{ACKNOWLEDGMENT}

We are thankful to farmer Usman Ali 286 J.B. Toba Tek Singh for carrying out this experiment on his field. We are also thankful to Shakarganj Sugar Research Institute, Jhang for providing seed, carrying out yield/sugar analysis and technical support for this experiment.

\section{REFERENCES}

Alam MJ, Rahman MK, Kabir ML, Hossain MS and Islam AKMR. 2006. Comparative performance of newly released sugarcane varieties in southern region of Bangladesh. Bangladesh $\mathrm{J}$ Sugarcane, 28: 14-18.

Chattha, A. A., M. Rafique, M. Afzal, F. Ahmed and M. Bilal (2006). Prospects of sugar industry \& sugarcane cultivation in Punjab. Proceedings of $41^{\text {th }}$ Annual Convention of Pakistan Society of Sugar Technologists held at Rawalpindi on August 21-22, 2006. p. 173-181.

Chattha, M. U. and Ehsanullah (2003). Agro-quantitative and qualitative performance of different cultivars and strains of sugarcane (Saccharum officinarum L.). Pakistan Sugar J. 18(06):2-5.

Economic Survey of Pakistan; 2017-18, Ministry of Finance, Government of Pakistan.

Gill, M. B. (1995). Physio agronomic studies on flat versus pit plantation of autumn and spring sugarcane (Saccharum officinarum L.). M.Sc. Thesis, Department of Agronomy, University of Agriculture, Faisalabad. p.49-89.

Islam MS, Hossain GMA, Alam KM, Islam S, Haque MA. 2016. Response of BSRI Akh 42 and soil properties to fertilizer doses in Chittagong Hill Tracts of Bangladesh. Bangladesh J Sugarcane. 37: 25-32.

Junejo SG, Kaloi M, Panhwar RN, Chohan M, Junejo AA, Soomro AF. 2010. Performance of newly developed sugarcane genotypes for some qualitative and quantitative traits under Thatta conditions J. Plant Anim. Sci.; 20(1): 40-43. 
Lal M, Singh AK (2008). Multiple ratooning for high cane productivity and sugar recovery. In: Proceedings of National Seminar on varietal planning for improving productivity and sugar recovery in sugarcane held at G.B.P.U.A. \& T. Pantnagar. 14(15):62-68.

Matin MA, Rahman ABMM and Ali MY. 1989. Performance of three sugarcane varieties as transplant and ratoon cane under rainfed condition. Bangladesh J Sugarcane. 11: 32-36.

Mian, A. M. (2006). Sugarcane variety composition in Pakistan. Proceedings of Seminars on Agriculture. Organized by Pakistan Society of Sugar Technologists held at Faisalabad on $19^{\text {th }}$ June 2006. pp.107-121.

MO, K., RK, G., \& MI, H. (2018). Suitability of Newly Released Sugarcane Varieties in Farmers Field Condition under High Ganges River Floodplain of Bangladesh. International Journal of Plant Biology \& Research.

Steel R.G.D., Torrie J.H. and Dickey D.A. 1997. Principles and procedures of statistics. A biometrical approach. 3rd Ed. McGraw Hill Book Co., Inc. New York, USA. pp. 400-428.

Anonymous. 1970. Laboratory Manual for Queens Land Sugar Mills. (5th Ed.) Watson, Ferguson and Co. pp. 94-150. 